\title{
Cellular Actions of Insulin-Like Growth Factor Binding Proteins
}

\author{
R. J. Ferry Jr., L. E. L. Katz, Adda Grimberg, P. Cohen, and S. A. Weinzimer \\ Division of Endocrinology/Diabetes, Department of Pediatrics, The Children's Hospital of \\ Philadelphia and The University of Pennsylvania, Philadelphia, Pennsylvania, USA
}

\begin{abstract}
The insulin-like growth factors (IGFs), insulin-like growth factor binding proteins (IGFBPs), and the IGFBP proteases are involved in the regulation of somatic growth and cellular proliferation both in vivo and in vitro. IGFs are potent mitogenic agents whose actions are determined by the availability of free IGFs to interact with the IGF receptors. IGFBPs comprise a family of proteins that bind IGFs with high affinity and specificity and thereby regulate IGF-dependent actions. IGFBPs have recently emerged as IGF-independent regulators of cell growth. Various IGFBP association proteins as well as cleavage of IGFBPs by specific proteases modulate levels of free IGFs and IGFBPs. The ubiquity and complexity of the IGF axis promise exciting discoveries and applications for the future.
\end{abstract}

\section{Keywords \\ IGF; IGFBP; IGF-lndependent; IGFBP Protease; Apoptosis; Cancer}

\section{Introduction}

The insulin-like growth factors (IGF-I and IGF-II), insulin-like growth factor binding proteins (IGFBPs), and IGFBP proteases are involved in the regulation of somatic growth and cellular proliferation, in vitro and in vivo. IGFs are potent mitogenic agents whose actions are determined by the availability of free IGFs to interact with the IGF receptors. The level of free IGF in a system is modulated by rates of IGF production and clearance and the degree of binding to IGFBPs. The IGFBPs comprise a superfamily of six proteins (IGFBP-1 to -6) that bind to IGFs with high affinity and specificity and proteins which bind IGFs with low affinity (IGFBP related proteins $1-4$ or IGFBP-rPs). IGFBPs not only regulate IGF action and bioavailability, but also appear to mediate IGF-independent actions, including inhibition or enhancement of cell growth and induction of apoptosis (programmed cell death). IGFBPs are produced by a variety of different tissues, and each tissue has specific levels of IGFBPs. Cleavage of IGFBPs by proteases plays a key role in modulating levels and actions of free IGFs and IGFBPs. Finally, many IGFBP association proteins have

\footnotetext{
(c) Georg Thieme Verlag Stuttgart
}

Requests for reprints should be addressed to: Pinchas Cohen, M.D., Associate Professor and Fellowship Program Director, Division of Pediatric Endocrinology/Diabetes, The Children's Hospital of Philadelphia, Abramson Pediatric Research Center, Room 410D, 3615 Civic Center Boulevard, Philadelphia PA 19104-4318, USA, Phone: +1 (215) 590-4504, Fax: + 1 (215) 590-1605,

cohenp@email.chop.edu. 
been discovered recently which can affect IGFBP action. This review aims to summarize recently gained insights about the cellular actions of IGFBPs.

\section{In Vivo Physiology of IGFBPs}

Most of the IGF-I and IGF-II molecules in serum are found in a 150-kDa ternary complex formed by an IGF, IGFBP-3, and a glycoprotein known as the acid labile subunit (ALS) [1]. A small proportion of IGFs is carried by other IGFBPs, and less than $1 \%$ of IGFs circulate in the free forms (Fig. 1) [1]. ALS is found nearly exclusively in the intravascular space, and the ternary complex does not cross the capillary barrier [2]. The half-life of the 150-kDa complex in serum is an order of magnitude longer than either free IGF-I or free IGFBP-3 [3]. Due to the absence of ALS in tissues, most tissue IGFs are bound to IGFBPs as binary complexes leaving only small amounts of local free IGF.

The liver produces most of the circulating IGFs although physiologically important autocrine and paracrine production occurs within other tissues [4]. The liver also produces most of the circulating IGFBP-3 and ALS, and different hepatic components produce different components of the ternary complex [4]. Hepatic endothelia and Kupffer cells synthesize IGFBP-3, while hepatocytes make IGF-I and ALS [5,6,7]. Growth hormone stimulates hepatic production of all three components of the 150-kDa complex [8-13].

IGFBP-3 is the most abundant IGFBP in post-natal serum, existing at levels an order of magnitude higher than other IGFBPs. IGFBP-3 levels do not change acutely [14], in contrast to IGFBP-1 and -2 levels, which vary throughout the day depending on the metabolic state $[13,15]$. The regulators of IGFBP-4, -5 , and -6 in serum have not been well studied yet; however, their levels have been shown to be age-dependent [16 - 18].

\section{Evolution of the High-Affinity IGFBPs}

Six IGFBPs with high affinity to IGFs have been identified to date. The first five IGFBPs demonstrate high affinity for both IGF-I and IGF-II, share at least 50\% homoloy among themselves, and share $80 \%$ homology between different species [12,19]. Most IGFBPs show higher affinity for IGF-I than IGF-II, except IGFBP-6, which has a 100-fold higher affinity to IGF-II versus IGF-I [16]. Several molecules with low affinity for IGFs have been described recently, including IGFBP-7 and putative IGFBP-8, -9, and -10. Homology among IGFBPs is most conserved at the $\mathrm{N}$ - and $\mathrm{C}$-terminal regions, while the middle region bears little similarity across different IGFBPs [1]. IGFBPs share a highly conserved set of at least 16 cysteine residues, which can form disulfide bridges to stabilize their tertiary structures [14].

The evolutionary conservation of IGFBPs supports their importance in the regulatory processes. IGFBP genes lie in close proximity to Homeobox gene clusters Hox A through Hox D which produce DNA-binding proteins that may have co-evolved with IGFBPs. Some investigators speculate that Hox and IGFBP genes originated from common ancestral genes which repeatedly underwent coordinated duplications and translocations [20 - 22]. 
The IGFBPs have several potential functions (Table 1 and Fig. 2). Classically, IGFBPs exert their actions indirectly through modulation of IGFs. Recently, IGFBPs have been shown to act independently of IGFs to impact crucial cell actions such as growth and apoptosis.

\section{Biochemistry, Regulation, and Physiology of High-Affinity IGFBPs}

\section{Insulin-like growth factor binding protein 1}

The IGFBP-1 gene is located on chromosome 7 [22]. IGFBP-1 is a 25-kDa protein with an RGD sequence in its structure $[19,23]$. Integrin receptors in the cell membrane recognize the RGD sequence suggesting the possibility of an IGF-independent action via these receptors [23].

IGFBP-1 is produced in the liver, decidua, and kidneys, and is the most abundant IGFBP in amniotic fluid. IGFBP-1 is found in various phosphorylated states that determine its affinity for IGFs [24]. Serum IGFBP-1 levels are predominantly regulated by insulin and corticosteroids. After meals, serum IGFBP-1 levels fall to less than $10 \mathrm{ng} / \mathrm{mL}$, but during fasting, IGFBP-1 levels rise to over $100 \mathrm{ng} / \mathrm{dL}$ [14]. In children with ketotic hypoglycemia who underwent diagnostic fasting studies, their IGFBP-1 levels were as high as $700 \mathrm{ng} / \mathrm{dL}$ at times of hypoglycemia (serum glucose $<60 \mathrm{mg} / \mathrm{dL}$ ) [25].

Insulin and corticosteroids regulate serum IGFBP-1 levels through transcriptional control of hepatic IGFBP-1 synthesis. Several studies have shown that insulin inhibits the synthesis of IGFBP-1, resulting in elevated levels during low insulin states such as intrauterine growth retardation, fasting, or poorly controlled Type 1 diabetes mellitus [14,16,26,27,28]. The inverse has also been shown, namely conditions of hyperinsulinemia decrease IGFBP-1 levels, including the post-prandial period, obesity, large for gestational age infants, insulinomas, and congenital hyperinsulinism with hypoglycemia [25]. Glucocorticoids and glucagon stimulate IGFBP-1 production in synergism with low levels of insulin [28-33]. Some cytokines (TNF- $\alpha$, IL-1 $\beta$, and IL-6) can also stimulate IGFBP-1 in vitro and in vivo [34].

In chronic renal failure, IGFBP-1 levels rise due to increased renal production [14]. In diabetes mellitus and renal failure, high IGFBP-1 levels are thought to have a pathophysiologic role - presumably decreasing the levels of free IGFs to interact with the IGF-I receptor - and elevated IGFBP-1 may be responsible for the decreased linear growth seen in these conditions. Moreover, compared to wild-type mice, certain transgenic mice which overproduce IGFBP-1 have significantly lower birthweights, poorer post-natal weight gain, and disproportionately smaller brains [35]. Murphy et al. demonstrated that such homozygous mice also demonstrate fasting hyperglycemia, impaired glucose tolerance and reduced fertility, suggesting that IGFBP-1 inhibitis metabolic as well as growth-promoting effects of IGFs [35]. Another transgenic mouse which had equally high levels of serum IGFBP-1 did not confirm the growth retardation observed in Murphy's model [36].

\section{Insulin-like growth factor binding protein 2}

The gene for IGFBP-2 is located on the long arm of chromosome 2 [22]. IGFBP-2 is a 31kDa protein [19]. Like 1GFBP-1, IGFBP-2 has an RGD sequence, but IGFBP-2 has not 
been demonstrated to bind integrin-type receptors. IGFBP-2 may associate with the cell surface via glycosaminoglycans, and presumably proteoglycans, if high concentrations of IGF-I or -II are present [37,38]. IGFBP-2 is neither phosphorylated nor glycosylated.

Concentrations of IGFBP-2 are age-dependent with high levels seen in infancy and older age and low levels in young adults [39]. The concentration of IGFBP-2 in seminal plasma, about $10000 \mathrm{ng} / \mathrm{mL}$, is the greatest level of any IGFBP in any biological fluid [40]. IGFBP-2 is the major IGFBP in cerebrospinal fluid due to its production by multiple neural tissues [41]. IGFBP-2 levels are elevated in the spinal fluid of patients with certain tumors of the central nervous system [42]. Growth hormone deficiency increases the serum level of IGFBP-2 in vivo even though growth hormone seems to have no direct effect on IGFBP-2 gene expression in cultured cells $[14,43]$. Regulation of IGFBP-2 expression also depends on insulin and the metabolic state albeit to a lesser degree than IGFBP-1 [44].

IGFBP-2 levels increase with prolonged fasting and respond more sensitively to protein restriction than to caloric restriction [15]. IGFBP-2 is elevated in malnutrition and anorexia nervosa [15], Untreated insulin-dependent diabetics - who have low levels of insulin - have elevated levels of IGFBP-2, and these levels return toward normal with long-term insulin therapy [27]. Although IGFBP-2 can be produced in vitro by multiple cell systems [42,44], its regulators in vivo remain largely unknown. In human neuroblastoma cells, retinoic acid reduces IGFBP-2 expression [41].

\section{Insulin-like growth factor binding protein 3}

The IGFBP-3 gene is located on chromosome 7, next to the IGFBP-1 gene [22]. IGFBP-3 has three glycosylation sites and resides in the circulation in various glycosylated forms weighing between 40 and 44kDa [14]. Non-glycosylated IGFBP-3 weighs $29 \mathrm{kDa}$ [45].

Serum levels of IGFBP-3 and IGFs vary similarly with age: starting low at birth, increasing during childhood, peaking during puberty, and decreasing thereafter [14,46], Nutrition affects the IGF-I level more than the IGFBP-3 level [14]. Low IGF-I levels were observed in chronic diseases and malnutrition while IGFBP-3 remained relatively unchanged [1315,26]. Although estrogens, parathormone (PTH), and glucocorticoids regulate IGFs and IGFBPs in the circulation, growth hormone $(\mathrm{GH})$ is the primary regulator in vivo of IGFBP-3 expression [14,47].

The mechanism by which GH stimulates IGFBP-3 production is still under investigation. Three proposed mechanisms are: (a) a direct effect of GH on Kupffer cells; (b) an indirect effect mediated by IGF-I; and (c) stimulation of non-hepatic tissues. Support for the first mechanism came from in vitro studies of human hepatocarcinoma cells, which demonstrated that GH increased IGFBP-3 gene expression independently of IGF-I [48]. Several in vitro studies support the second mechanism.

In a large population of $\mathrm{GH}$ receptor-deficient patients from Ecuador, however, administration of IGF-I stimulated growth but did not change IGFBP-3 levels by radioimmunoassay (RIA) [8,49]. However, in a similar population from Israel, IGF-I increased levels of IGFBP-3 by Western ligand blotting (unfortunately, this study did not 
utilize IGFBP-3 RIA) [50]. One explanation for these findings postulates that IGF-I did not stimulate production of IGFBP-3, but instead protected IGFBP-3 from proteolysis. In support of this notion are some animal models in which IGF-I induces serum IGFBP-3 as detected by ligand blotting [51]. In support of the third mechanism, some in vitro studies have shown that: (a) GH can induce IGFBP-3 message expression in many tissues (rat liver, skin, and muscle); and (b) IGF-I can induce an increase in serum IGFBP-3 concentration in the absence of an increase in hepatic IGFBP-3 mRNA levels and despite a paucity of liver IGF-I Type 1 receptor mRNA [52].

IGFBP-3 is also produced in a variety of non-hepatic tissues [53] and can be regulated by many compounds other than GH. Stimulation of bone cells with growth hormone (but not IGF-I) caused an increase in IGFBP-3 expression [54]. Depending on the tissue studied, IGFBP-3 expression has been shown to be regulated in vitro by interleukin-1 [55], tumor necrosis factor-alpha (TNF-a) [55,56], transforming growth factor-beta (TGF- $\beta$ ) [57], retinoic acid [58], PTH [14], osteogenic protein-1 [59], estradiol [60], prostaglandin E2 [61], glucocorticoids [47], and p53 [62]. Though thought to be predominantly a serum and extracellular protein, IGFBP-3 has been shown to localize to the nuclei of lung cancer cells [63].

IGFBP-3 can promote or inhibit growth both in vivo and in vitro. Effects of IGFBP-3 can be either IGF-mediated or IGF-independent. Transgenic mice have been developed which express a human IGFBP-3 transgene in small bowel, colon, and kidney, as detected by Northern analysis, but do not have increased serum IGFBPs by Western ligand blotting [64], Of note, the majority of serum hIGFBP-3 in these transgenic mice was not associated with ALS. Compared to genetically related, wild-type mice and to nontransgenic littermates, the transgenic mice demonstrated selective organomegaly affecting heart, liver, and spleen [64]. Birth, body, brain and kidney weights as well as litter size did not differ significantly between transgenic mice and nontransgenics [64]. In a different model, rat ventral prostate following castration rapidly increased gene expression of IGFBP-2 through -5 in association with apoptosis [65]. In another model, the hIGFBP-3 gene was transfected into a cell line derived from an IGF receptor "knock-out" mouse which is non-IGF responsive [66]. Cell growth decreased significantly in this model, proving definitively that IGFBP-3 inhibits cell growth independently of the IGF-IR [66]. Later in this review, we will detail further support for IGFBP-3 as an IGF-in-dependent modulator of cell growth.

\section{Insulin-like growth factor binding protein 4}

The gene for IGFBP-4 is located on chromosome 17 [22]. IGFBP-4 has been identified in all biological fluids [4] and exists at its predicted molecular weight of $24 \mathrm{kDa}$ or in the glycosylated form weighing $28 \mathrm{kDa}$ [14]. Different cell types produce IGFBP-4 locally, including fibroblasts, neuroblastoma cells, prostate cells, and bone cells [41,67]. IGFBP-4 can bind cell membranes (with as yet unknown function), but the majority of IGFBP-4 exists as extracellular solute [3]. The regulatory mechanisms affecting IGFBP-4 expression remain poorly understood. In bone, IGFBP-4 is regulated by vitamin D and PTH $[67,68]$. In neuroblastoma cells, retinoic acid inhibits IGFBP-4 [41]. 


\section{Insulin-like growth factor binding protein $\mathbf{5}$}

IGFBP-5 weighs $29 \mathrm{kDa}$ and can be found in several glycosylated forms weighing between 29 and $32 \mathrm{kDa}$ [14]. Like IGFBP-2, the IGFBP-5 gene is located on chromosome 2 [22]. Like IGFBP-3, IGFBP-5 levels decrease with age, starting after puberty. Levels in older women are approximately $30 \%$ of teenagers $[17,18]$. Fetal tissues have high levels of IGFBP-5 during rapid growth [14] but tissue levels in adults vary. Connective tissues and cerebrospinal fluid (CSF) have substantial concentrations of IGFBP-5, and IGFBP-5 is the main IGFBP expressed in the kidney [14]. IGFBP-5 can also form ternary complexes with IGFs and ALS [69].

Unlike other IGFBPs, IGFBP-5 strongly binds to bone cells due to its high affinity for hydroxyapatite [44]. Like IGFBP-3, IGFBP-5 binds to endothelial cell monolayers and is found in large concentrations in the extracellular matrix (ECM). Its binding to endothelia is competitively inhibited by heparin and heparan sulfate, and alteration near the C-terminus of IGFBP-5 inhibit its binding to cells but not to the ECM [70]. IGFBP-5 binds the ECM on an ionic basis. When bound to the ECM, IGFBP-5's affinity for IGF-I is seven- to twelve-fold reduced compared to intact IGFBP-5 in solution [71].

In vitro studies showed that IGFBP-5 stimulated IGF-I actions when compared to IGF-I alone [72]. The IGF-enhancing actions of IGFBP-5 are particularly evident in bone cells. Studies suggest a need for IGFBP- 5 to be bound to the cell membrane or to extracellular matrix to cause this potentiation [72]. IGFBP-5 bound to the extracellular matrix has lower affinity for IGF-I than does free IGFBP-5, but this bound form has a prolonged half-life [72]. Binding of IGF-I to the matrix-bound IGFBP-5 facilitates subsequent binding of IGF-I to its receptors [72].

The regulatory mechanisms for IGFBP-5 are still under investigation. Serum levels of IGFBP-5 have recently been shown to be GH-dependent [18]. Bone cells produce large amounts of IGFBP-5, and levels decrease during maturation due to protease activity. Treatment of osteoblastic cells with fibroblast growth factor, TGF- $\beta$ and platelet-derived growth factor BB caused a decrease in IGFBP-5 expression [73]. In the same cell system, treatment with IGF-I and retinoic acid caused the opposite effect, increasing levels of IGFBP-5 mRNA [73,74]. IGFBP-5 levels in fibroblasts and osteoblast-like cells decreased when glucocorticoids were added to the cells $[47,75]$. In smooth muscle cells, IGFBP-5 mRNA expression is stimulated by IGF-I via a mechanism which is time-dependent, dosedependent, and cell type-specific [76].

\section{Insulin-like growth factor binding protein 6}

The gene for IGFBP-6 resides on chromosome 12 [22]. IGFBP-6 is an O-glycosylated protein [76] with a predicted molecular weight of $34 \mathrm{kDa}$ [4]. Human IGFBP-6 is found predominantly in CSF and serum [14]. It is the only IGFBP that preferentially binds IGF-II over IGF-I by more than two orders of magnitude $[16,77,78]$. In osteoblastic cells, the addition of excessive concentration of IGFBP-6 inhibited IGF-II-stimulated DNA and glycogen synthesis, but had minimal effects on inhibiting IGF-I actions [16]. IGFBP-6 is expressed in ovarian cells, prostatic cells, fibroblasts and other cells [77]. Expression of 
IGFBP-6 is regulated by IGF-II and other hormones. Studies in breast carcinoma cell lines showed that: 1) in the cells studied, only estrogen receptor-negative cells produced IGFBP-6; and 2) IGFBP-6 expression was not changed by IGF-I but was enhanced by retinoic acid [79]. In human osteoblast cells, retinoic acid increases IGFBP-6 expression by more than $1000 \%$ [80].

\section{IGFBP proteases}

While an extensive review of IGFBP proteolysis is beyond the scope of this review, we will describe the physiology of IGFBP proteolysis using specific examples. IGFBP proteolysis was first described in pregnancy serum as proteolytic activity against IGFBP-3, and prostate specific antigen (PSA) in seminal plasma was the first IGFBP protease to be biochemically identified [81]. To date, proteolysis of IGFBP-2 to -6 has been described in multiple clinical states and cellular systems. Categories of IGFBP proteases include kallikreins [81,82], cathepsins [83-86], and matrix metalloproteinases proteases (MMPs) [87-89].

Kallikrein-like serine proteases which cleave IGFBP-3 include PSA, gamma-nerve growth factor, and plasmin [90]. In fact, plasmin degrades multiple IGFBPs [90]. Thrombin, another serine protease, cleaves IGFBP-5 at physiologically relevant concentrations, i.e., within one order of magnitude of fibrinogen, its natural substrate [91].

Cathepsins are intracellular proteinases which are activated by acidic conditions and may be relevant to certain physiologic and pathological processes including neoplastic infiltration. Under these conditions in vivo, a high release of hydrogen ions may provide an acidic environment for extracellular cathepsin action which-through interaction with the IGF axismay be related to cell growth rates [92]. MMPs (also called matrixins) comprise a family of peptide hydrolases (2800 to $92000 \mathrm{kDa}$ ) responsible for the degradation of extracellular matrix components such as collagen and proteoglycans in processes involving tissue remodeling. These peptide hydrolases require a metal ion for their catalytic activity and thus are inactivated by metal chelators as well as by specific inhibitors. An IGFBP protease in mouse pregnancy serum belongs to the MMP family, as does a zinc-dependent protease produced by dermal fibroblasts. MMPs have been identified in prostatic fluid and cells. The IGFBP protease induced in airway smooth muscle cell culture by inflammatory agents (leukotriene D4 and inter-leukin 1- $\beta$ ) has been identified as MMP-1 by immunoblotting and immunoprecipitation techniques [93].

Proteolytic activity may play a role in normal and abnormal tissue proliferation by cleavage of IGFBPs into fragments with lower affinity for IGFs. Lower-affinity IGFBP fragments allow increased levels of free IGFs to activate IGF receptors (Fig. 1). For example, PSAgenerated IGFBP-3 fragments have decreased affinity for IGFs, and prostatic epithelial cells grown in the presence of PSA demonstrate reversal of the inhibitory effects of IGFBP-3 on IGF-stimulated cell growth [93]. Pregnancy serum protease may play a role in regulating IGF bioactivity by making IGFs more available to the cells [94].

IGFBP proteases are also important autocrine/paracrine growth regulators. They have been implicated in physiologic processes such as ovarian follicular growth and atresia [95].

IGFBP proteases may be the critical elements in malignant and benign proliferative diseases 
including prostate cancer and airway smooth muscle hyperplasia of long-standing asthma [89].

Regulation of IGFBP proteolysis is a new area of investigation. Recent papers have revealed intriguing observations. In vivo, the IGFBP-3 protease activity detectable in the serum of newly diagnosed youngsters with insulin-dependent diabetes mellitus appears to be reversible by insulin [96], IGFs stimulate but IGFBPs inhibit an IGFBP-4 protease of MC3T3-E1 osteoblasts [97]. Similar findings have been demonstrated in dermal fibroblasts [98]. The IGFBP-3 protease secreted by MCF-7 breast cancer cells can be inhibited by IGFs, suggesting a unique loop by which IGFs can regulate their own activity [99]. Such findings implicate the relative proportion of IGFs to IGFBPs to be a critical regulator of IGFBP proteases.

\section{IGF-Dependent Actions of IGFBPs}

IGFBPs clearly modulate the interactions between IGFs and Type I IGF receptors on the cell surface (Fig. 2). IGFs are potent mitogens, and many in vitro systems have demonstrated that all IGFBPs have growth-inhibitory effects by competitively binding IGFs and preventing their binding to the IGF-IR. The most powerful evidence supporting this sequestration mechanism has come from studies using the IGF-I analog des-(1-3)-IGF-I which binds IGF-IR and stimulates DNA synthesis, but does not bind IGFBP-3. In the human promyeloid cell line HL-60, adding IGFBP-3 to serum-free media inhibited cell proliferation induced by IGF-I and IGF-II but not by des-IGF-I [100]. Transfected ishikawa endometrial cancer cells which overexpressed both IGF-IR and cell membrane-bound IGFBP-3 demonstrated equal IGF-IR binding by IGF-I and des-(1-3)-IGF-I [101]. In this cancer cell line, membrane-bound IGFBP-3 inhibited growth induced by IGF-I and not by des-(1-3)-IGF-I [101]. Similar sequestration effects have been demonstrated in human osteoarthritic chondrocytes [102] and human granulosa cells [103]. A comparison of serum levels of IGF-I and IGF-II versus IGFBP-2 through -5 in bovine first-wave dominant follicles showed that the IGF-I/IGFBP ratio decreased with atresia of the follicles [104]. Studies in vivo have also suggested that IGFBPs inhibit growth by reducing the free IGF level [105,106]. A new twist on IGFBP regulation of IGFs came from Binoux et al. who reported that IGFBP-3 may directly inhibit IGF binding to the IGF-IR, an alternative to inhibition through extracellular sequestration [107].

As mentioned earlier, IGFs can regulate IGFBP gene expression which would provide paracrine or autocrine feedback loops. IGF-I has been shown to stimulate release of IGFBP-3, but not IGFBP-4, in a lung cancer cell line [108]. Under strict in vitro conditions, IGFBP-1, -3 , and -5 can enhance IGF actions by enhancing IGF-I binding to IGF-IR (Fig. 2) [109]. IGFBP-1, -2, and possibly -4 can also transport IGFs between the intra- and extravascular space [110]. In proliferating opossum kidney cells, Li et al. recently demonstrated that fluorescent IGF-I and IGFBP-3 - whether added to media in combination or alone - were absorbed from the media and colocalized to the nucleus [111]. These fascinating observations suggest that IGFBP-3 may ferry IGF-I to the cell nucleus, providing another regulatory mechanism for IGF action. 


\section{IGF-Independent Actions of IGFBPs and IGFBP Receptors}

The discovery of IGF-independent modulation of growth by IGFBPs provided evidence for the presence of specific cell-surface IGFBP receptors and added a further layer of complexity to the IGF axis (Fig. 1). An accumulating body of evidence has revealed that IGFBP-3 has important IGF-independent effects in vitro on growth regulation in multiple cells and tissues. Unfortunately, in vivo studies to date (including those in transgenic animals or with infusions into human subjects) have not shown direct, inhibitory, IGF-independent effects of IGFBP-3, even though such models produced high serum levels of free IGFBP-3.

Transfection of the IGFBP-3 gene into murine fibroblasts inhibited cell growth by a mechanism that was not reversible by the addition of excess insulin, even though insulin has mitogenic activity in these cells, does not bind IGFBP-3, and would presumably saturate the IGF-IR [112]. Binoux et al. generated a 16-kDa fragment of rhIGFBP-3 (by proteolysis with plasmin) with negligible binding affinity for IGF-I and presumably none for insulin [113]. This IGFBP-3 fragment inhibited insulin- and IGF-I-stimulated DNA synthesis in chick embryo fibroblasts [113]. The same fragment also inhibited mitogenesis in murine fibroblasts with a defective IGF-IR that could respond to bFGF but not IGF, epidermal growth factor, or platelet-derived growth factor PDGF [114]. Fibroblasts not expressing IGF-IR derived from IGF-IR knockout mice demonstrated marked growth inhibition when transfected with a vector containing the IGFBP-3 gene [115]. This growth inhibition correlated with the magnitude of IGFBP-3 expression in these clones [115]. Because these cells did not express IGF receptors, the growth-inhibiting effects of IGFBP-3 clearly were mediated not through an IGF-IR pathway but presumably through a novel, IGFBP-3-specific pathway.

The existence of cell-surface IGFBP-3 association proteins/receptors was first suggested by Oh et al., who demonstrated specific, dose-dependent binding of IGFBP-3 to breast cancer cell surface proteins of 20,26, and $50 \mathrm{kDa}[63,116]$. In these estrogen-receptor-negative breast cancer cells, the inhibitory effects of IGFBP-3 on growth were shown to be dosedependent and diminished by co-incubation with IGFs, but not by IGF analogs with reduced affinity for IGFBP-3. Rajah et al. detected specific IGFBP-3 association proteins in cell lysates (18- to 150-kDa) and membrane fractions $(18,-67-$, and $150-\mathrm{kDa})$ of the prostate cancer cell line PC-3 [117]. The addition of exogenous IGFBP-3 to PC-3 cells resulted in a dose-dependent increase in the apoptotic index which was only partially attenuated by the addition of IGF-I and unchanged by the addition of IGF analogs with reduced affinity to IGFBP-3. Confirmation of the direct action of IGFBP-3 on apoptosis was achieved by the induction of apoptosis by IGFBP-3 in IGF-IR-negative (knockout) murine fibroblasts. Using specific anti-sense oligonucleotides and neutralizing, anti-IGFBP-3 antibodies to block IGFBP-3 expression and action, IGFBP-3 was identified as the mediator of apoptosis induced by retinoic acid (RA) and transforming growth factor- $\beta$ (TGF- $\beta$ ) in multiple cell types $[58,60,117-119]$. Recently, a protein biochemically identified as the Type V TGF- $\beta$ receptor (by affinity cross-linking and immunoprecipitation techniques) was shown to bind IGFBP-3, and it may be another 1GFBP-3 association protein [120]. However, this protein has not been characterized structurally, and its size is several-fold larger than other putative IGFBP-3 receptors [120]. 


\section{IGF Stimulatory Roles of IGFBPs}

\section{Insulin-like growth factor binding protein 1}

Even though IGFBP-1 inhibits mitosis by removing free IGF-1 from the extracellular space, in some in vitro systems IGFBP-1 stimulates growth. IGFBP-1, in the presence of low concentration of platelet-poor plasma and IGF-I, stimulated DNA synthesis in porcine aortic smooth muscle cells, chick embryo fibroblasts, and mouse embryo fibroblasts [121,122]. Koistinen et al. concluded that IGFBP-1 caused slow and steady release of IGF-I when they found that concentrations that can inhibit IGF-I's binding to its receptor sometimes enhance IGF-stimulated thymidine incorporation [123]. The inhibition did not occur when IGFBP-1 was added without IGF-I, suggesting an effect due to the slow release of IGF-I and not due to a direct effect of IGFBP-1 $[123,124]$.

However, IGFBP-1 binds specifically to the a5 $\beta$-integrin receptor and stimulates cell migration of Chinese hamster ovarian cells in a monolayer wounding assay [125]. IGFBP-1 stimulates in vivo healing of rabbit ears when added with IGF-I, and this effect is dependent on binding of IGFBP-1 to the integrin receptor [126] (Fig. 2). IGFBP-1 has also been shown to stimulate wound healing in diabetic rabbits [127].

Other investigators showed that IGFBP-1 phosphorylation alters its effects. Phosphorylated IGFBP-1 has high affinity for IGF-I and probably inhibits IGF-I action, while dephosphorylated forms, as found in pregnancy serum, have low affinity and allow IGF actions $[128,129]$. Finally, IGFBP-1 may be involved in IGF-I transport through the capillary barrier, a process which in certain tissues appears to involve an insulin-dependent mechanism [130,131] (Fig. 2).

\section{Insulin-like growth factor binding protein 3}

Pre-incubation of fibroblasts with IGFBP-3 followed by its removal potentiated IGF-I effects on DNA synthesis in a dose-dependent fashion [53], even though addition of IGFBP-3 to conditioned media in the same cell system caused inhibition of cell growth [132]. The conclusion was that the presence of large amounts of IGFBP-3 caused reduction in the free IGF levels, while small amounts of IGFBP-3 protected IGFs, intensifying their effects. When cells were pre-incubated with IGFBP-3 and then washed, low molecular weight forms of IGFBP-3, probably representing proteolysed fragments, were bound to the cell membrane [53].

The proposed mechanism for the difference between the effects of pre-incubated and soluble IGFBP-3 is that IGFBP-3 fragments bound to the cell membrane have an order of magnitude lower affinity for IGF-I than does intact soluble IGFBP-3. Intact soluble IGFBP-3 has higher affinity for IGFs than to IGF-IR. Indeed, the affinity of IGF-I for the membrane bound IGFBP-3 fragment is lower than that for the Type I IGF receptor. Thus, IGFBP-3 might function as a reservoir of IGF-I, presenting and slowly releasing IGF-I to interact with its receptor, while protecting the receptor from down-regulation. In support of this latter concept, Conover and Powell showed that the IGF-I receptor down-regulation induced by IGF-I can be prevented by IGFBP-3 via modulating the IGF-I availability for binding to its receptor [133]. 
In vivo studies have shown that topical use of IGFBP-3 in association with IGF-I leads to better wound healing than the use of IGF-I alone [134]. In another study, the administration of IGFBP-3 and IGF-I to growth hormone deficient rats caused better growth than the administration of IGF-I alone [135]. In the same study, however, IGFBP-3 protected the rats from the hypoglycemic effects of IGF-I. Incubation of bladder smooth muscle cells with either IGFBP-3 or IGFBP-5 resulted in an increase in rates of proliferation, and addition of IGFs potentiated this stimulatory effect [136]. Thus, it appears that IGFBP-3 targets IGF-I towards growth provocation and away from the insulin-sensitive glucose-consuming tissues.

\section{Insuln-like growth factor binding protein $\mathbf{5}$}

Several in vitro studies showed that IGFBP-5 stimulated IGF-I actions when compared to IGF-I alone $[53,72,109,136]$. The IGF-enhancing actions of IGFBP-5 are particularly evident in bone cells [72]. Studies suggest a need for IGFBP-5 to be bound to the cell membrane or to extracellular matrix to cause this potentiating effect $[53,72]$. Compared to free IGFBP-5, IGFBP-5 bound to the extracellular matrix has lower affinity for IGF-I, but a prolonged half life [53,71]. The binding of IGF-I to the matrix-bound IGFBP-5 facilitates subsequent binding of IGF-I to its receptors [53,71,109].

\section{Possible Intracellular Roles of IGFBPs}

IGFBP-3 and IGFBP-5 have recently been shown to be translocated into the nucleus compatible with having a nuclear localization sequence (NLS) in their mid-region $[63,108,137,138]$. IGFBP-3 has also been shown to bind importin, a molecule that facilitates nuclear transport [139]. Nuclear IGFBP-3 may directly control gene expression. Of note, IGFBP-3 interacts with a plethora of molecules which may regulate IGFBP-3 action on cells, including transferrin, heparin, and the latent TGF- $\beta$ binding protein (LTBP-1) $[140-$ 143].

Simian virus 40-transformed fibroblasts have dramatically lower IGFBP-5 expression compared to their normal counterparts [144,145]. Although this down-regulation may eventually prove to be an epiphenomenon, it still suggests an important role for IGFBP-5 in maintenance of the normal phenotype [144,145], Using several methods, we have shown that IGFBP-3 binds and interacts with the human papilloma virus oncoprotein E7 [142]. The discoveries that IGFBP-3 and IGFBP-5 interact with important viral oncoproteins implies additional roles for IGFBPs in the pathways of cell proliferation, apoptosis, and malignant transformation [138]. The structural determinants of IGFBP binding to their protein partners, including intracellular and extracellular ligands as well as cell surface and matrix molecules, will soon be unraveled and surely shine light on the molecular mechanisms of IGFBP actions [146-148].

\section{Acknowledgments}

This work was supported by grants NIH 1P50 HL 56398, NIH 2R01 DK47591, NIH R01 AI40203, and an American Cancer Society Idea Development Grant (PC); an NIH CAP Award (LELK); a PHS National Research Service Award (RJF); fellowship grants from Eli Lilly \& Co. and Pharmacia \& Upjohn (RJF, AC, SAW); The Lawson Wilkins Pediatric Endocrine Society Lilly Fellowship Award (AG); and The Lawson Wilkins Pediatric Endocrine Society Pharmacia-Upjohn Fellowship Award (SAW). 


\section{References}

1. Baxter RC. Insulin-like growth factor binding proteins in the human circulation, a review. Horm Res. 1994; 42:140-4. [PubMed: 7532612]

2. Khosravi MJ, Diamandi A, Mistry J, Krishna RG, Khare A. Acid-labile subunit of human insulinlike growth factor-binding protein complex: measurement, molecular, and clinical evaluation. J Clin Endocrinol Metab. 1997; 82(12):3944-51. comment in J Clin Endocrinol Metab 1997; 82 (12): 3941 - 3. [PubMed: 9398693]

3. Hasegawa T, Cohen P, Rosenfeld RG. Characterization of the insulin-like growth factor axis in TM 3 Leydig cells. Growth Rel. 1995; 5:151-9.

4. Cohen, P.; Rosenfeld, RG. The IGF axis. In: Rosenbloom, AL., editor. Human Growth Hormone, Basic and Scientific Aspects. Boca Ration FL: CRC Press; 1995. p. 43-58.

5. Arany E, Afford S, Strain AJ, et al. Differential cellular synthesis of insulin-like growth factor binding protein 1 and IGFBP-3 within human liver. J Clin Endocrinol Metab. 1994; 79:1871-6. [PubMed: 7527416]

6. Chin E, Zhou J, Dai J, et al. Cellular localization of gene expression for components of the IGF ternary complex. Endocrinol. 1994; 134:2498-504.

7. Villafuerte BC, Koop BL, Pao C, et al. Coculture of primary rat hepatocytes and nonparenchimal cells permits expression of insulin-like growth factor binding protein-3 in vitro. Endocrinology. 1994; 134:2044-50. [PubMed: 7512496]

8. Rosenfeld RG, Pham H, Cohen P, et al. Insulin-like growth factor binding proteins and their regulation. Acta Paediatr. 1994; 339(Suppl):154-8.

9. Ballard J, Baxter R, Binoux M, et al. Report on the nomenclature of the IGF binding proteins. Endocrinology. 1992; 130:1736-7. [PubMed: 1371456]

10. Cohen P, Fielder PJ, Hasegawa Y, et al. Clinical aspects of insulin-like growth factor binding proteins. Acta Endocrinol. 1991; 124:74-85. [PubMed: 1713010]

11. Holly JMP, Martin JL. IGFBPs: a review of methodological aspects of their purification, analysis and regulation. Growth Regul. 1994; 4(Suppl):20-30. [PubMed: 7515739]

12. Lamson G, Giudice LC, Rosenfeld RG. Insulin-like growth factor binding proteins: structural and molecular relationships. Growth Factors. 1991; 5:19-28. [PubMed: 1722987]

13. Underwood LE, Thissen JP, Lemozy, et al. Hormonal and nutritional regulation of IGF-I and its binding proteins. Horm Res. 1994; 42:145-51. [PubMed: 7532613]

14. Katz LEL, Rosenfeld RG, Cohen P, et al. Clinical significance of insulin-like growth factor binding proteins (IGFBPs). Endocrinologist. 1995; 5(1):36-43.

15. Smith WJ, Underwood LE, Clemmons DR. Effects of caloric or protein restriction on insulin-like growth factor-I (IGF-I) and IGF-binding proteins in children and adults. J Clin Endocrinol Metab. 1995; 80(2):443-9. [PubMed: 7531712]

16. Baxter RC, Saunders H. Radioimmunoassay of insulin-like growth factor-binding protein-6 in human serum and other body fluids. J Endocrinol. 1992; 134:133-9. [PubMed: 1380056]

17. Mohan S, Farley JR, Baylink DJ. Age-related changes in IGFBP-4 and IGFBP-5 levels in human serum and bone: implications for bone loss with aging. Prog Growth Factor Res. 1995; 6(2-4): 465-73. [PubMed: 8817691]

18. Mohan S, Libanati C, Dony C, Lang K, Srinivasan N, Baylink DJ. Development, validation, and application of a radioimmunoassay for insulin-like growth factor binding protein-5 in human serum and other biological fluids. J Clin Endocrinol Metab. 1995; 80(9):2638-45. [PubMed: 7545694]

19. Shimasaki S, Ling N. Identification and molecular characterization of insulin-like growth factor binding proteins (IGFBP-1, -2, -3, -4, -5, and -6). Prog Growth Factor Res. 1991; 3:243-66. [PubMed: 1725860]

20. Hong YS, Kim SY, Bhattacharya A, et al. Structure and function of the HOX Al human homebox gene cDNA. Gene. 1995; 159:209-14. [PubMed: 7622051] 
21. Matsui T, Hirai M, Hirano M, et al. The HOX complex neighbored by the EVX gene, as well as two other homeobox-containing genes, the GBX-class and the EN-class, are located on the same chromosomes 2 and 7 in humans. FEBS Let. 1993; 336:107-10. [PubMed: 7903253]

22. Allander SV, Bajalica S, Larsson C, et al. Structure and chromosomal localization of human insulin-like growth factor-binding protein genes. Growth Regul. 1993; 3:3-5. [PubMed: 7683522]

23. Ruoslathi E, Pierschlaber MD. New perspectives in cell adhesions: RGD and integrins. Science. 1987; 238:491-7. [PubMed: 2821619]

24. Coverley JA, Baxter RC. Phosphorylation of insulin-like growth factor binding proteins. Mol Cell Endocrinol. 1997; 128(1-2):1-5. [PubMed: 9140069]

25. Katz LEL, Satin-Smith MS, Collett-Solberg P, Thornton PS, Baker L, Stanley CA, Cohen P. Insulin-like growth factor binding protein-1 levels in the diagnosis of hypoglycemia caused by hyperinsulinism (comment in: J Pediatr 131 [2]: 171 - 3 [1997]). J Pediatr. 1997; 131(2):193-9. [PubMed: 9290603]

26. Counts DR, Gwirtsman H, Carlsson LMS, et al. The effect of anorexia nervosa and refeeding on growth hormone binding protein, the insulin-like growth factors (IGFs) and the IGF-binding proteins. J Clin Endocrinol Metab. 1992; 75(3):762-7. [PubMed: 1381372]

27. Strasser-Vogel B, Blum WF, Past R, et al. Insulin-like growth factor (IGF)-I and -II and IGFbinding proteins- $1,-2$, and -3 in children and adolescents with diabetes mellitus. Correlation with metabolic control and height attainment. J Clin Endocrinol Metab. 1995; 80(4):1207-13. [PubMed: 7536202]

28. Unterman TG, Oehler DT, Murphy LJ, et al. Multihormonal regulation of insulin-like growth factor binding protein-1 in rat H4IIE hepatoma cells: the dominant role of insulin. Endocrinology. 1991; 128:2693-701. [PubMed: 1709855]

29. Katz LE, Satin-Smith MS, Collett-Solberg P, Baker L, Stanley CA, Cohen P. Dual regulation of insulin-like growth factor binding protein-1 levels by insulin and Cortisol during fasting. J Clin Endocrinol Metab. 1998; 83(12):4426-30. [PubMed: 9851789]

30. Conover CA, Divertie GD, Lee PD. Cortisol increases plasma isulin-like growth factor binding protein-1 in humans. Acta Endocrinol. 1993; 128:140-3. [PubMed: 7680833]

31. Lee PDK, Conover CA, Powell DR. Regulation and function of insulin-like growth factor binding protein-1. Proc Soc Exp Biol Med. 1993; 204:4-29. [PubMed: 7690486]

32. Price WA, Stiles AD, Moats-Staats BM, et al. Gene expression of insulin-like growth factors (IGFs), the type I IGF receptor, and the IGF-binding proteins in dexamethasone-induced fetal growth retardation. Endocrinology. 1990; 130:1424-32. [PubMed: 1371449]

33. Conover CA, Lee PD, Riggs BL, Powell DR. Insulin-like growth factor binding protein-1 expression in cultured human bone cells: regulation by insulin and glucocorticoids. Endocrinology. 1996; 137(8):3295-3301. [PubMed: 8754754]

34. Samstein B, Hoimes ML, Fan J, Frost RA, Gelato MC, Lang CH. IL-6 stimulation of insulin-like growth factors binding proteins (IGFBPs) production. Biochem Biophys Res Commun. 1996; 228(2):611-5. [PubMed: 8920958]

35. Murphy LJ, Rajkumar K, Molnar P. Phenotypic manifestations of insulin-like growth factor binding protein-1 (IGFBP-1) and IGFBP-3 overexpression in transgenic mice. Prog Growth Factor Res. 1995; 6(2-4):425-32. [PubMed: 8817686]

36. Gutierrez-Ospina G, Calikoglu AS, Ye P, D'Ercole AJ. In vivo effects of insulin-like growth factorI on the development of sensory pathways: analysis of the primary somatic sensory cortex (SI) of transgenic mice. Endocrinology. 1996; 137(12):5484-92. [PubMed: 8940375]

37. Russo VC, Bach LA, Fosang AJ, Baker NL, Werther CA. Insulin-like growth factor binding protein-2 binds to cell surface proteoglycans in the rat brain olfactory bulb. Endocrinology. 1997; 138(11):4858-67. [PubMed: 9348216]

38. Arai T, Busby W Jr, Clemmons DR. Binding of insulin-like growth factor (IGF) 1 or II to IGFbinding protein-2 enables it to bind to heparin and extracellular matrix. Endocrinology. 1996; 137(11):4571-5. [PubMed: 8895319]

39. Cohen $P$, Noveral JP, Bhala A, et al. Leukotriene $D_{4}$ facilitates airway smooth muscle cell proliferation via modulation of the IGF axis. Amer J Physiol. 1995; 269(13):L151-L7. [PubMed: 7544535] 
40. Schwander J, Mary JL. The RIA for IGFBP-2 in man: a meagre catch? Growth Regul. 1993; 3:105-9.

41. Bernardini S, Cianfarani S, Spagnoli A, et al. Expression and down-regulation by retinoic acid of IGF binding protein-2 and -4 in medium from human neuroblastoma cells. J Neuroendocrine. 1994; 6(4):409-13.

42. Müller HL, Oh Y, Lehrnbecher T, et al. Insulin-like growth factor binding protein-2 concentrations in cerebrospinal fluid and serum of children with malignant solid tumors or acute leukemia. J Clin Endocrinol Metab. 1994; 79(2):428-34. [PubMed: 7519190]

43. Hardouin S, Gurmelem M, Noguiez P, et al. Molecular forms of serum insulin-like growth factor (IGF)-binding proteins in man: relationship with growth hormone and IGFs and physiologic significance. J Clin Endocrinol Metab. 1989; 69(6):1291-301. [PubMed: 2555386]

44. Kelley KM, Oh Y, Gargosky SE, Gucef Z, Matsumoto T, Hwa I, Ng L, Simpson DM, Rosenfeld RG. Insulin-like growth factor-binding proteins (IGFBPs) and their regulatory dynamics. Intern J Biochem Cell Biol. 1996; 28(6):619-37.

45. Sommer A, Spratt SK, Tatsuno GP, et al. Properties of glycosylated and nonglycosylated human recombinant IGF binding protein-3 (IGFBP-3). Growth Regul. 1992; 3:46-9. [PubMed: 7683528]

46. Paolisso G, Ammendola S, Del Buono A, et al. Serum levels of insulin-like growth factor-I (IGF-I) and IGF-binding protein-3 in healthy centenarians: relationship with plasma leptin and lipid concentrations, insulin action, and cognitive function. J Clin Endocrinol Metab. 1997; 82(7):22049. [PubMed: 9215295]

47. Conover CA, Clarkson JT, Bale LK. Effect of glucocorticoid on insulin-like growth factor (IGF) regulation of IGF-binding protein expression in fibroblasts. Endocrinol. 1995; 136(4):1403-10.

48. Gucev ZS, Oh Y, Kelley KM, et al. Evidence for insulin-like growth factor (IGF)-independent transcriptional regulation of IGF binding protein-3 by growth hormone in SKHEP-1 human hepatocarcinoma cells. Endocrinology. 1997; 138(4):1464-70. [PubMed: 9075703]

49. Vaccarello MA, Diamond FB, Guevara-Aguirre J, et al. Hormonal and metabolic effects and pharmacokinetics of recombinant insulin-like growth factor-I in growth hormone receptor deficiency/Laron syndrome. J Clin Endocrinol Metab. 1993; 77:273-80. [PubMed: 7686916]

50. Kanety H, Karasik A, Klinger B, et al. Long-term treatment of Laron type dwarfs with insulin-like growth factors increases serum IGFBP-3 in the absence of growth hormone activity. Acta Endocrinol. 1993; 128:144-9. [PubMed: 7680834]

51. Zapf J, Hauri C, Waldvogel M, et al. Recombinant human IGF-I induces its own specific carrier proteins in hypophysectomized and diabetic rats. Proc Natl Acad Sci USA. 1989; 86:3813-7. [PubMed: 2471192]

52. Lemmey AB, Glassford J, Flick-Smith HC, Holly JM, Pell JM. Differential regulation of tissue insulin-like growth factor-binding protein (IGFBP)-3, IGF-I and IGF type 1 receptor mRNA levels, and serum IGF-I and IGFBP concentrations by growth hormone and IGF-I. J Endocrinol. 1997; 154(2):319-28. [PubMed: 9291843]

53. Conover, CA.; Clarkson, JT.; Durham, SK., et al. Cellular actions of insulin-like growth factor binding protein-3. In: LeRoith, D.; Raizada, MK., editors. Current Directions in Insulin-like Growth Factor Research. New York: Plenum Press; 1994. p. 255-65.

54. Kanzaki S, Baxter RC, Knutsen R, et al. Evidence that human bone cells in culture secrete insulinlike growth factor (IGF)-II and IGF binding protein-3 but not acid-labile subunit both under basal and regulated conditions. J Bone Mineral Res. 1995; 10(6):854-8.

55. Olney RC, Wilson DM, Mohtai M, Fielder PJ, Smith RL. Interleukin-1 and tumor necrosis factoralpha increase insulin-like growth factor-binding protein-3 (IGFBP-3) production and IGFBP-3 protease activity in human articular chondrocytes. J Endocrinol. 1995; 146(2):279-86. [PubMed: 7561640]

56. Besset V, Le Magueresse-Battistoni B, Collette J, Benahmed M. Tumor necrosis factor alpha stimulates insulin-like growth factor binding protein 3 expression in cultured porcine Sertoli cells. Endocrinology. 1996; 137(1):296-303. [PubMed: 8536626]

57. Oh Y, Müller HL, Ng L, Rosenfeld RG. Transforming growth factor- $\beta$-induced cell growth inhibition in human breast cancer cells is mediated through insulin-like growth factor-binding protein-3 action. J Biol Chem. 1995; 270:13589-92. [PubMed: 7539790] 
58. Han GR, Dohi DF, Lee HY, et al. All-trans-retinoic acid increases transforming growth factorbeta2 and insulin-like growth factor binding protein-3 expression through a retinoic acid receptoralpha-dependent signaling pathway. J Biol Chem. 1997; 272(21):13711-6. [PubMed: 9153223]

59. Hayden JM, Strong DD, Baylink DJ, Powell DR, Sampath TK, Mohan S. Osteogenic protein-1 stimulates production of insulin-like growth factor binding protein-3 nuclear transcripts in human osteosarcoma cells. Endocrinology. 1997; 138(1):4240-7. [PubMed: 9322936]

60. Huynh H, Yang YF, Pollak M. Estradiol and antiestrogens regulate a growth inhibitory insulin-like growth factor binding protein 3 autocrine loop in human breast cancer cells. J Biol Chem. 1996; 271:1016-21. [PubMed: 8557625]

61. DiBattista JA, Dore S, Morin N, Abribat T. Prostaglandin E2 up-regulates insulin-like growth factor binding protein-3 expression and synthesis in human articular chondrocytes by a c-AMPindependent pathway: role of calcium and protein kinase A and C. J Cell Biochem. 1996; 63(3): 320-33. [PubMed: 8913883]

62. Buckbinder L, Talbott R, Velasco-Miguel S, et al. Induction of the growth inhibitor IGF-binding protein 3 by p53. Nature. 1995; 377(6550):646-9. [PubMed: 7566179]

63. Jaques G, Noll K, Wegmann B, et al. Nuclear localization of insulin-like growth factor binding protein 3 in a lung cancer cell line. Endocrinology. 1997; 138(4):1767-70. [PubMed: 9075742]

64. Murphy LJ, Molnar P, Lu X, Huang H. Expression of human insulin-like growth factor-binding protein-3 in transgenic mice. J Mol Endocrinol. 1995; 15(3):293-303. [PubMed: 8748136]

65. Nickerson T, Pollak M, Huynh H. Castration-induced apoptosis in the rat ventral prostate is associated with increased expression of genes encoding insulin-like growth factor binding proteins 2,3,4, and 5. Endocrinology. 1998; 139(2):807-10. [PubMed: 9449659]

66. Oh Y, Müller HL, Lamson G, Rosenfeld RG. Insulin-like growth factor (IGF)-independent action of IGF-binding protein-3 in Hs578T human breast cancer cells. Cell surface binding and growth inhibition. J Biol Chem. 1993; 268:14964-71. [PubMed: 7686909]

67. Mohan S, Nakao Y, Honda Y, Landale E, Leser U, Dony C, Lang K, Baylink DJ. Studies on the mechanisms by which insulin-like growth factor (IGF) binding protein-4 (IGFBP-4) and IGFBP-5 modulate IGF actions in bone cells. J Biol Chem. 1995; 270(35):20424-31. [PubMed: 7544787]

68. Scharla AH, Strong DD, Mohan S, et al. 1,25-Dihydroxivitamin D3 differentially regulates the production of insulin-like growth factor I (IGF-I) and IGF-binding protein-4 in mouse osteoblasts. Endocrinology. 1991; 129:3139-46. [PubMed: 1720089]

69. Twigg SM, Baxter RC. Insulin-like growth factor (IGF)-binding protein 5 forms an alternative ternary complex with IGFs and the acid-labile subunit. J Biol Chem. 1998; 273(11):6074-9. [PubMed: 9497324]

70. Booth BA, Boes M, Andress DL, et al. IGFBP-3 and IGFBP-5 association with endothelial cells: role of C-terminal heparin binding domain. Growth Regul. 1995; 5(1):1-17. [PubMed: 7538367]

71. Jones JI, Gockerman A, Busby WH Jr, et al. Extracellular matrix contains insulin-like growth factor binding protein-5; potentiation of the effects of IGF-I. J Cell Biol. 1993; 121(3):679-87. [PubMed: 7683690]

72. Andress DL, Birnbaum RS. Human osteoblast-derived insulin-like growth factor (IGF) binding protein-5 stimulates osteoblast mitogenesis and potentiates IGF action. J Biol Chem. 1992; 267:22467-72. [PubMed: 1385400]

73. Canalis E, Gabbitas B. Skeletal growth factors regulate the synthesis of insulin-like growth factor binding protein-5 in bone cell cultures. J Biol Chem. 1995; 270(18):10771-6. [PubMed: 7537737]

74. Conover CA, Bale LK, Clarkson JT, et al. Regulation of insulin-like growth factor binding protein-5 messenger ribonucleic acid expression and protein availability in rat osteoblast-like cells. Endocrinology. 1993; 132:2525-30. [PubMed: 7684979]

75. Okazaki R, Riggs BL, Conover CA. Glucocorticoid regulation of insulin-like growth factorbinding protein expression in normal human osteoblast-like cells. Endocrinology. 1994; 134(1): 126-32. [PubMed: 7506203]

76. Duan C, Hawes SB, Prevette T, et al. Insulin-like growth factor-I (IGF-I) regulates IGF-binding protein-5 synthesis through transcriptional activation of the gene in aortic smooth muscle cells. J Biol Chem. 1996; 271(8):4280-8. [PubMed: 8626775] 
77. Bach LA, Thotakura NR, Rechler MM. Human insulin-like growth factor binding protein-6 is Oglycosylated. Growth Regul. 1993; 3(1):59-62. [PubMed: 7683533]

78. Claussen M, Buergisser D, Schuller AG, et al. Regulation of insulin like growth factor (IGF)binding protein-6 and mannose 6-phosphate/IGF-II receptor expression in IGF-II overexpres-sing NIH 3T3 cells. Mol Endocrinol. 1995; 9(7):902-12. [PubMed: 7476972]

79. Sheikh MS, Shao ZM, Hussain A, et al. Regulation of insulinlike growth factor-binding protein -1, 2, 3, 4, 5, 6: synthesis, secretion, and gene expression in estrogen receptor-negative human breast carcinoma cells. J Cell Physiol. 1993; 155(3):556-67. [PubMed: 7684042]

80. Zhou Y, Mohan S, Linkhart TA, et al. Retinoic acid regulates insulin-like growth factor-binding protein expression in human osteoblast cells. Endocrinology. 1996; 137(3):975-83. [PubMed: 8603611]

81. Cohen P, Graves HC, Peehl DM, Kamarei M, Giudice LC, Rosenfeld RG. Prostate-specific antigen (PSA) is an insulin-like growth factor binding protein-3 protease found in seminal plasma. J Clin Endocrinol Metab. 1992; 75(4):1046-53. [PubMed: 1383255]

82. Rajah R, Bhala A, Nunn SE, Peehl DM, Cohen P. 7S nerve growth factor is an insulin-like growth factor binding protein protease. Endocrinology. 1996; 137(7):2676-82. [PubMed: 8770886]

83. Conover C, DeLeon DD. Acid activated insulin-like growth factor binding protein-3 proteolysis in normal and transformed cells. Role of cathepsin D. J Biol Chem. 1994; 2691:7076-80. [PubMed: 7510281]

84. Conover C, Perry J, Tindall D. Endogenous cathepsin-D-mediated hydrolysis of insulin-like growth factor-binding proteins in cultured human prostatic carcinoma cells. J Clin Endocrinol Metab. 1995; 80:987-93. [PubMed: 7533776]

85. Nunn S, Peehl DM, Cohen P. Acid-activated insulin-like growth factor binding protein protease activity of cathepsin D in normal and malignant prostatic epithelial cells and seminal plasma. J Cell Physiol. 1997; 171(2):196-204. [PubMed: 9130467]

86. Claussen M, Kubler B, Wendland M, et al. Proteolysis of insulin-like growth factors (IGF) and IGF binding proteins by cathepsin D. Endocrinology. 1997; 138(9):3797-803. [PubMed: 9275067]

87. Fowlkes JL, Suzuki K, Nagase H, Thrailkill KM. Proteolysis of insulin-like growth factor binding protein-3 during rat pregnancy: a role for matrix metalloproteinases. Endocrinology. 1994; 135:2810-3. [PubMed: 7527335]

88. Fowlkes JL, Enghild JJ, Suzuki K, Nagase H. Matrix metalloproteinases degrade insulin-like growth factor binding protein-3 in dermal fibroblast cultures. J Biol Chem. 1994; 269(25):742-6.

89. Rajah R, Katz L, Nunn S, Solberg P, Beers T, Cohen P. Insulin-like growth factor binding protein proteases: functional regulators of cell growth. Prog Growth Factor Res. 1996; 6:273-84. [PubMed: 8817670]

90. Angelloz-Nicoud P, Harel L, Binoux M. Recombinant human insulin-like growth factor (IGF) binding protein-3 stimulates prostate carcinoma cell proliferation via an IGF-dependent mechanism. Role of serine proteases. Growth Regulation. 1996; 6(3):130-6. [PubMed: 8894645]

91. Zheng B, Clarke JB, Busby WH, Duan C, Clemmons DR. Insulin-like growth factor-binding protein-5 is cleaved by physiological concentrations of thrombin. Endocrinology. 1998; 139(4): 1708-14. [PubMed: 9528953]

92. Bereket A, Wilson TA, Kolasa AJ, Fan J, Lang CH. Regulation of the insulin-like growth factor sytem by acute acidosis. Endocrinology. 1996; 137(6):2238-45. [PubMed: 8641171]

93. Cohen P, Peehl DM, Graves HC, Rosenfeld RG. Biological effects of prostate specific antigen as an insulin-like growth factor binding protein-3 protease. J Endocrinol. 1994; 142(3):407-15. [PubMed: 7525824]

94. Blat C, Villaudy J, Binoux M. In vivo proteolysis of serum IGFBP-3 results in increased availability of IGF to target cells. J Clin Invest. 1994; 93:2286-90. [PubMed: 7514194]

95. Besnard N, Pisselet C, Zapf J, Hornebeck W, Monniaux D, Mon-get P. Proteolytic activity is involved in changes in intrafollicular insulin-like growth factor binding protein levels during growth and atresia of ovine ovarian follicles. Endocrinology. 1996; 137(5):1599-607. [PubMed: 8612491]

96. Bereket A, Lang CH, Blethen SL, Fan J, Frost RA, Wilson TA. Insulin-like growth factor binding protein-3 proteolysis in children with insulin-dependent diabetes mellitus: a possible role for 
insulin in the regulation of IGFBP-3 protease activity. J Clin Endocrinol Metab. 1995; 80(8): 2282-8. [PubMed: 7543110]

97. Fowlkes JL, Thrailkill KM, George-Nascimento C, Rosenberg CK, Serra DM. Heparin-binding, highly basic regions within the thyroglobulin type-1 repeat of insulin-like growth factor (IGF)binding proteins (IGFBPs) $-3,-5$, and -6 inhibit IGFBP-4 degradation. Endocrinology. 1997; 138(6):2280-5. [PubMed: 9165012]

98. Donnelly MJ, Holly JM. The role of IGFBP-3 in the regulation of IGFBP-4 proteolysis. J Endocrinol. 1996; 149(3):R1-R7. [PubMed: 8691093]

99. Salahifar H, Baxter RC, Martin JL. Insulin-like growth factor binding protein (IGFBP)-3 protease activity secreted by MCF-7 breast cancer cells: inhibition by IGFs does not require IGF-IGFBP interaction. Endocrinol. 1997; 138(4):1683-90.

100. Li YM, Schacher DH, Liu Q, et al. Regulation of myeloid growth and differentiation by the insulin-like growth factor I receptor. Endocrinology. 1997; 138(1):362-8. [PubMed: 8977425]

101. Karas M, Danilenko M, Fishman D, et al. Membrane-associated insulin-like growth factorbinding protein-3 inhibits insulin-like growth factor-I-induced insulin-like growth factor-I receptor signaling in ishikawa endometrial cancer cells. J Biol Chem. 1997; 272(26):16514-20. [PubMed: 9195961]

102. OIney RC, Tsuchiya K, Wilson DM, et al. Chondrocytes from osteoarthritic cartilage have increased expression of insulin-like growth factor I (IGF-I) and IGF-binding protein-3 (IGFBP-3) and -5, but not IGF-II or IGFBP-4. J Clin Endocrinol Metab. 1996; 81(3):1096-103. [PubMed: 8772582]

103. Barreca A, Artini PG, Cesarone A, et al. Interrelationships between follicle stimulating hormone and the growth hormone - insulin-like growth factor - IGF-binding proteins axes in human granulosa cells in culture. J Endocrinol Invest. 1996; 19(1):35-42. [PubMed: 8851690]

104. de la Sota RL, Simmen FA, Diaz T, Thatcher WW. Insulin-like growth factor system in bovine first-wave dominant and subordinate follicles. Biol Reprod. 1996; 55(4):803-12. [PubMed: 8879493]

105. Hasegawa Y, Hasegawa T, Fujii K, et al. High ratios of free to total insulin-like growth factor-I in early infancy. J Clin Endocrinol Metab. 1997; 82(1):156-8. [PubMed: 8989251]

106. Powell DR. Effects of renal failure on the growth hormone-insulin-like growth factor axis. $\mathbf{J}$ Pediatr. 1997; 131(1 Pt 2):S13-S16. [PubMed: 9255220]

107. Mohseni-Zadeh S, Binoux M. Insulin-like growth factor (IGF) binding protein-3 interacts with the type 1 IGF receptor, reducing the affinity of the receptor for its ligand: an alternative mechanism in the regulation of IGF action. Endocrinology. 1997; 138(12):5645-8. [PubMed: 9389554]

108. Noll K, Wegmann B, Havemann K, Jaques G. Insulin-like growth factors stimulate the release of insulin-like growth factor-binding protein-3 (IGFBP-3) and degradation of IGFBP-4 in nonsmall cell lung cancer cell lines. J Clin Endocrinol Metab. 1996; 81:2653-62. [PubMed: 8675593]

109. Jones JJ, Clemmons DR. Insulin-like growth factors and their binding proteins: biological actions. Endocrinol Rev. 1995; 16(1):3-34.

110. Ranke MB, Elmlinger M. Functional role of insulin-like growth factor binding proteins. Horm Res. 1997; 48(Suppl 4):9-15. [PubMed: 9350439]

111. Li W, Fawcett J, Widmer HR, Fielder PJ, Rabkin R, Keller GA. Nuclear transport of insulin-like growth factor-I and insulin-like growth factor binding protein-3 in opossum kidney cells. Endocrinology. 1997; 138(4):1763-6. [PubMed: 9075741]

112. Cohen P, Lamson G, Okajima T, Rosenfeld RG. Transfection of the human insulin-like growth factor binding protein-3 gene into Balb/c fibroblasts inhibits cellular growth. Mol Endocrinol. 1993; 7:380-6. [PubMed: 7683373]

113. Lalou C, Lassarre C, Binoux M. A proteolytic fragment of insulin-like growth factor (IGF) binding protein-3 that fails to bind IGFs inhibits the mitogenic effects of IGF-I and insulin. Endocrinology. 1996; 137:3206-12. [PubMed: 8754741]

114. Zadeh SM, Binoux M. The 16-kDa proteolytic fragment of insulin-like growth factor (IGF) binding protein-3 inhibits the mitogenic action of fibroblast growth factor on mouse fibroblasts 
with a targeted disruption of the type 1 IGF receptor gene. Endocrinology. 1997; 138(7):306972. [PubMed: 9202255]

115. Valentinis B, Bhala A, DeAngelis T, Baserga R, Cohen P. The human insulin-like growth factor (IGF) binding protein-3 inhibits the growth of fibroblasts with a targeted disruption of the IGF-I receptor gene. Mol Endocrinol. 1995; 9:361-7. [PubMed: 7539889]

116. Oh Y, Müller HL, Pham H, Rosenfeld RG. Demonstration of receptors for insulin-like growth factor binding protein-3 on Hs578T human breast cancer cells. J Biol Chem. 1993; 268(35): 26045-48. [PubMed: 7504671]

117. Rajah R, Valentis B, Cohen P. Insulin-like growth factor (IGF)-binding protein-3 induces apoptosis and mediates the effects of transforming growth factor- $1 \beta$ on programmed cell death via a p53- and IGF-independent mechanism. J Biol Chem. 1997; 272(18):12181-8. [PubMed: 9115291]

118. Gucev ZS, Oh Y, Kelley KM, Rosenfeld RG. Insulin-like growth factor binding protein 3 mediates retinoic acid- and transforming growth factor $\beta 2$-induced growth inhibition in human breast cancer cells. Cancer Res. 1996; 56:1545-50. [PubMed: 8603400]

119. Erondu NE, Dake BL, Moser DR, Lin M, Boes M, Bar RS. Regulation of endothelial IGFBP-3 synthesis and secretion by IGF-I and TGF-beta. Growth Regulation. 1996; 6(1):1-9. [PubMed: 8717444]

120. Leal SM, Liu Q, Huang SS, Huang JS. The type V transforming growth factor beta receptor is the putative insulin-like growth factor-binding protein-3 receptor. J Biol Chem. 1997; 272(33): 20572-6. [PubMed: 9252371]

121. Clemmons DR, Gardner LI. A plasma factor is required for IGFBP-1 to potentiate DNA synthesis. J Cell Physiol. 1990; 145:129-35. [PubMed: 1698793]

122. Elgin RG, Busby WH, Clemmons DR. An insulin-like growth factor binding protein enhances the biologic reponse to IGF-I. Proc Natl Acad Sci USA. 1987; 84:3254-8. [PubMed: 2953025]

123. Koistinen R, Itkinen $P$, Selenius $P$, et al. Insulin-like growth factor binding protein-1 inhibits binding of IGF-I on fetal skin fibroblasts but stimulates their DNA synthesis. Biochem Bio-phys Res Commun. 1990; 173:408-15.

124. Clemmons DR, Cascieri MA, Camacho-Hubner C, et al. Discrete alterations of the IGF-I molecule which alter its affinity for IGF binding proteins result in changes in bioactivity. $\mathrm{J}$ Biol Chem. 1990; 265:12210-6. [PubMed: 1695626]

125. Jones JI, Gockerman A, Busby WH Jr, Wright G, Clemmons DR. Insulin-like growth factor binding protein 1 stimulates cell migration and binds to the alpha 5 beta 1 integrin by means of its Arg-Gly-Asp sequence. Proc Natl Acad Sci USA. 1993; 90(22):10553-7. [PubMed: 7504269]

126. Galiano RD, Zhao LL, Clemmons DR, Roth SI, Lin X, Mustoe TA. Interaction between the IGF family and the integrin receptor family in tissue repair processes. Evidence in a rabbit ear dermal ulcer model. J Clin Invest. 1996; 98(11):2462-8. [PubMed: 8958208]

127. Tsuboi R, Shi CM, Sato C, Cox GN, Ogawa H. Co-administration of insulin-like growth factor (IGF)-I and IGF-binding protein-1 stimulates wound healing in animal models. J Invest Derm. 1995; 104(2):199-203. [PubMed: 7530269]

128. Jyung RW, Mustoe TA, Busby WH, et al. Increased wound breaking strength induced by insulinlike growth factor-I in combination with IGF binding protein-1. Surgery. 1994; 115:133-239.

129. Clemmons, DR. Role of post translational modifications in modifying the biologic activity of insulin like growth factor binding proteins. In: LeRoith, D.; Raizada, MK., editors. Current Directions in Insulin-like Growth Factor Research. New York: Plenum Press; 1994. p. 245-53.

130. Lewitt MS, Saunders H, Cooney GJ, et al. Effect of human insulin-like growth factor binding protein-1 on the half life and action of administered insulin-like growth factor in rats. J Endocrinol. 1993; 136:253-60. [PubMed: 7681466]

131. Bar RS, Boes M, Clemmons DR, et al. Insulin differentially alters transcapillary movement of intravascular IGFBP-1, IGFBP-2 and endothelial cell IGF binding proteins in rat heart. Endocrinology. 1990; 127:497-9. [PubMed: 1694498]

132. DeMellow JSM, Baxter RC. Growth hormone-dependent insulin-like growth factor (IGF) binding protein both inhibits and potentiates IGF-I stimulated DNA synthesis in human skin fibroblasts. Biochem Biophys Res Commun. 1988; 156:199-204. [PubMed: 2972283] 
133. Conover CA, Powell DR. Insulin-like growth factor (IFG)-binding protein-3 blocks IGF-Iinduced receptor down-regulation and cell desensitization in cultured bovine fibroblasts. Endocrinology. 1991; 129:710-6. [PubMed: 1713161]

134. Hamon GA, Hunt TK, Spencer EM. In vivo effects of systemic insulin-like growth-I alone and complexed with insulin-like growth factor binding protein-3 on corticosteroid suppressed wounds. Growth Regul. 1993; 3:55-6.

135. Clark RG, Mortensen D, Reifsynder D, et al. Recombinant human insulin-like growth factor binding protein-3 (rhIGFBP-3): effects on the glycemic and growth promoting activities of rhIGF-I in the rat. Growth Regul. 1993; 3:50-2. [PubMed: 7683530]

136. Weinzimer, SA.; Macarak, E.; Cohen, P. The role of the IGF-IGFBP axis in the regulation of bladder smooth muscle growth. Program \& Abstracts of the 80th Annual Meeting of the Endocrine Society; New Orleans LA, USA. June 1998; Held

137. Schedlich LJ, Young TF, Firth SM, Baxter RC. Insulin-like growth factor-binding protein (IGFBP)-3 and IGFBP-5 share a common nuclear transport pathway in T47D human breast carcinoma cells. J Biol Chem. 1998; 273(29):18347-52. [PubMed: 9660801]

138. Wraight, CJ.; Liepe, IJ.; Werther, GA. Intracellular localisation of insulin-like growth factor binding protein-3 during mitosis in human keratinocytes. Program \& Abstracts of the 4th International Symposium on Insulin-like Growth Factors; Tokyo, Japan. 1997.

139. Noll, K.; Hochscheid, R.; Wegmann, B., et al. Hints for the nuclear import and location of insulin-like growth factor binding protein-3 in lung cancer cell lines. Program \& Abstracts of the 4th International Symposium on Insulin-like Growth Factors; Tokyo, Japan. 1997.

140. Hodgkinson S, Fowke P, Al Somai N, McQuoid M. Proteins in tissue extracts which bind insulinlike growth factor binding protein-3 (IGFBP-3). J Endocrinol. 1995; 145:Rl-R6.

141. Yang YWH, Yanagishita M, Rechler MM. Heparin inhibition of insulin-like growth factor binding protein-3 (IGFBP-3) binding to human fibroblasts and rat glioma cells: role of heparan sulfate proteoglycans. Endocrinology. 1996; 137:4363-71. [PubMed: 8828497]

142. Cohen, P. Cell regulatory functions of IGFBP-3. Program \& Abstracts of the 80th Annual Meeting of The Endocrine Society (New Orleans LA); Bethesda, MD. 1998. p. 32

143. Xu, W.; Murphy, LJ. Interaction of IGFBP-3 with latent transforming growth factor-p binding protein-1 identified using the yeast two-hybrid system. Program \& Abstracts of the 80th Annual Meeting of The Endocrine Society (New Orleans LA); Bethesda, MD. 1998. p. 313

144. Schenker T, Trueb B. Down-regulated proteins of mesenchymal tumor cells. Exp Cell Res. 1998; 239(1):161-8. [PubMed: 9511734]

145. Reeve JG, Guadano A, Xiong J, Morgan J, Bleehen NM. Diminished expression of insulin-like growth factor (IGF) binding protein-5 and activation of IGF-I-mediated autocrine growth in simian virus 40-transformed human fibroblasts. J Biol Chem. 1995; 270(1):135-42. [PubMed: 7529226]

146. Spencer EM, Chan K. A 3-dimensional model for the insulinlike growth factor binding proteins (IGFBPs); supporting evidence using the strutural determinants of the IGF binding site on IGFBP-3. Prog Growth Factor Res. 1995; 6(2-4):209-14. [PubMed: 8817663]

147. Hashimoto R, Ono M, Fujiwara H, et al. Binding sites and binding properties of binary and ternary complexes of insulin-like growth factor-II (IGF-II), IGF-binding protein-3, and acidlabile subunit. J Biol Chem. 1997; 272(44):27936-42. [PubMed: 9346943]

148. Firth SM, Ganeshprasad U, Baxter RC. Structural determinants of Iigand and cell-surface binding of insulin-like-growth factor-binding protein-3. J Biol Chem. 1998; 273(5):2631-8. [PubMed: 9446566] 


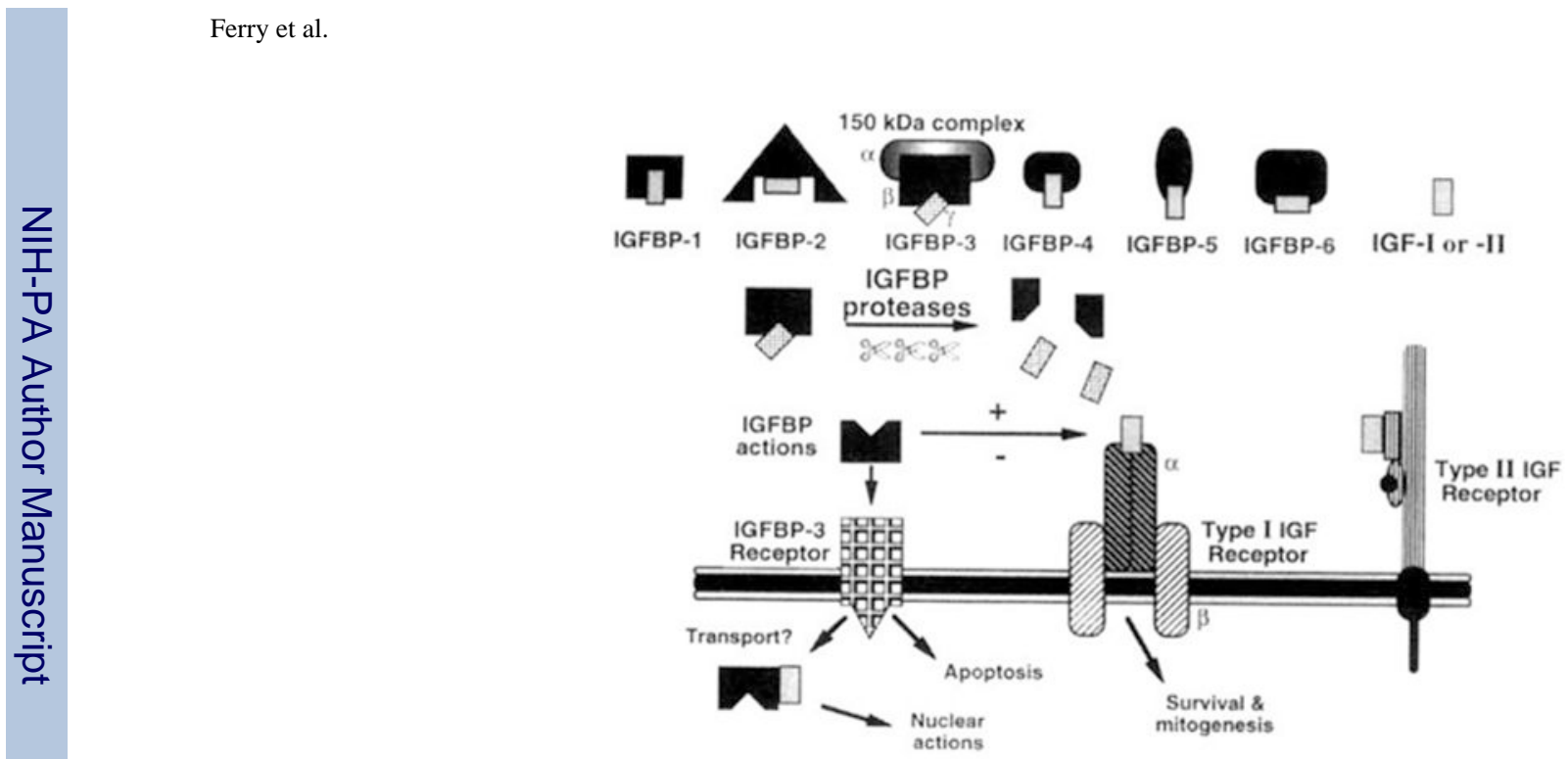

Fig. 1.

The IGF axis. See text for details. 

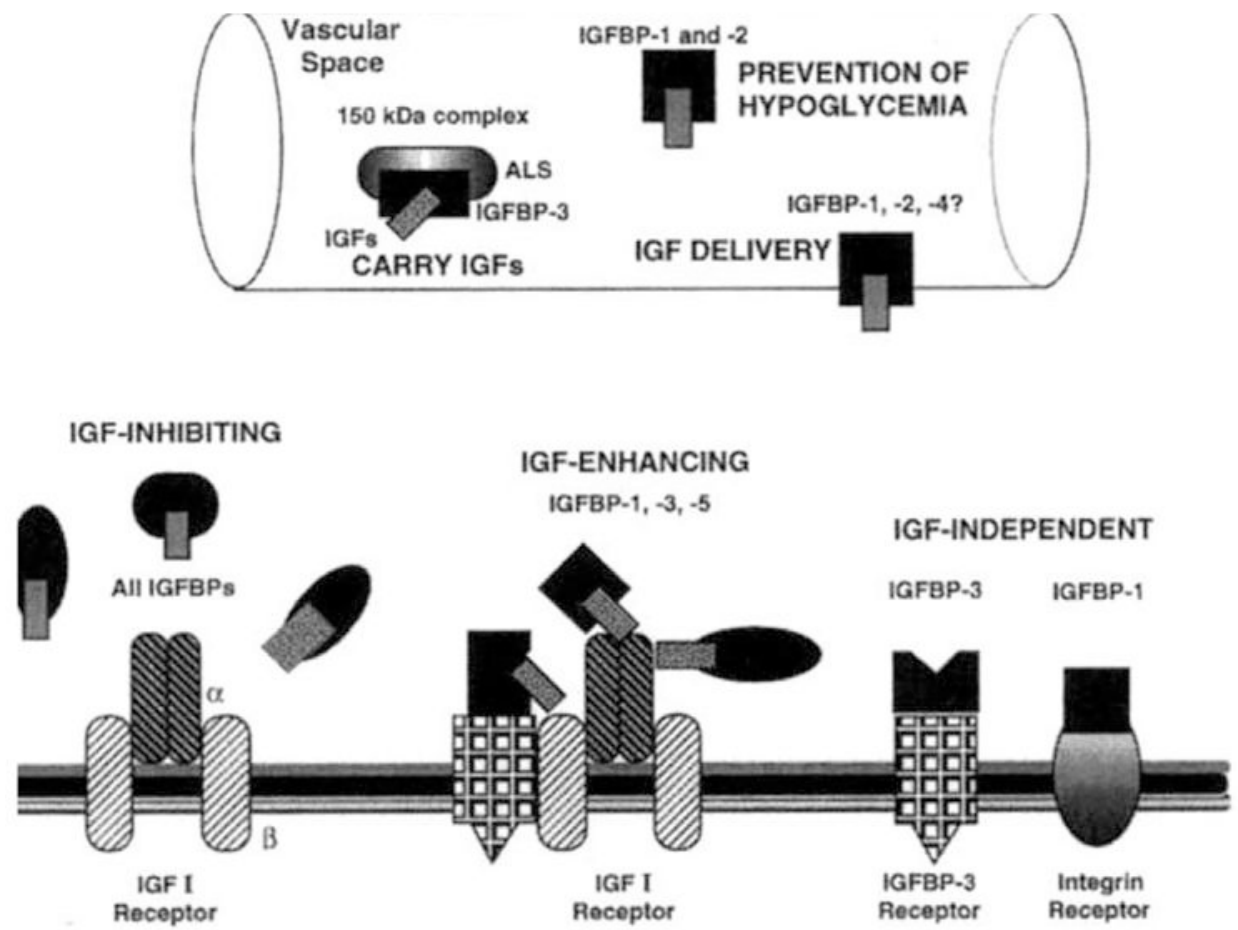

Fig. 2.

Roles of the IGFBPs in the intravascular space (A) and at the cell membrane (B). See text for details. 
Table 1

Functions of the insulin-like growth factor binding proteins

Limit bioavailability of free IGFs to bind IGF receptors

Prevent IGF-induced hypoglycemia

Regulate transport of IGFs between intra- and extravascular spaces

Prolong the half-life of IGFs in circulation

Enhance actions of IGFs by forming a slow-releasing pool of IGFs

Affect cellular proliferation/death via IGFBP receptors 